Article

\title{
Networked Social Enterprises: A New Model of Community Schooling for Disadvantaged Neighborhoods Facing Challenging Times
}

\author{
Kirstin Kerr * and Alan Dyson \\ Centre for Equity in Education, Manchester Institute of Education, Ellen Wilkinson Building, \\ University of Manchester, Manchester M13 9PL, UK; d.a.dyson@manchester.ac.uk \\ * Correspondence: kirstin.kerr@manchester.ac.uk; Tel.: +44-161-275-3464 \\ Academic Editor: Hal A. Lawson \\ Received: 26 April 2016; Accepted: 15 June 2016; Published: 23 June 2016
}

\begin{abstract}
Community schools have long been accepted as an institutional mechanism for intervening in the relationship between poverty, poor educational outcomes, and limited life chances. At a time when public services are being retracted, and disadvantaged places are being increasingly left to struggle, community schools are poised to become more important in offering a response to the needs of children, families, and communities in these places. Yet, despite their apparent promise, community schools remain badly under-conceptualized. As an international field, research on community schooling has rarely articulated or questioned how - by providing additional learning and leisure opportunities and personal and social supports—community schools might create a viable intervention in the relationship between poverty and poor outcomes. This paper explicitly addresses this significant challenge. Conceptualizing empirical findings emerging from a research-practice partnership, it identifies the core features of a new institutional design for community schools which can help to clarify their potential contribution to addressing disadvantage. Marking a considerable shift from a traditional design of simply adding new services to the school day, it argues that community schools will need to operate as social enterprises with networked governance arrangements, and to develop strategies which engage with children's social ecologies, and are risk-reducing and resilience-building within these. This, in turn, sets a new agenda for significantly advancing the field of community schooling by further defining-conceptually and empirically-the core elements of a new institutional design as identified here.
\end{abstract}

Keywords: community schools; new institutional designs; theory of change

\section{The Challenge}

Recent decades have seen affluent countries world-wide increasingly seeking to improve the quality of their schools and school systems-not least, as a means to ensure their economic competitiveness in globalized markets. Typically, while these efforts have met with some success, the drive for improvement is also resulting in a widening gap between learners whose socio-economic and cultural backgrounds disadvantage them in education when compared to their more advantaged peers [1-5]. Indeed, it is becoming increasingly clear that school improvement efforts alone are unable to narrow this growing gap [6,7]. As Muijs [6] (p. 89) argues:

Even if we found all the factors that make schools more or less effective, we would still not be able to affect more than 30 percent of the variance in pupils' outcomes. It has therefore become increasingly clear that a narrow focus on the school as an institution will not be sufficient to enable work on more equitable educational outcomes to progress... Interventions will need to impact more directly on pupils' environment and life chances. 
This has led to a growing interest internationally in schools taking on a wider remit, seeking to intervene in their students' 'environment and life chances' in addition to their core academic role. Initiatives to this end have appeared in many countries, taken many forms, and gone under many names, though the term 'community schools' is probably most commonly used [8-10]. There is, for instance, a strong 'community school' movement in the USA, which is both well-established and, importantly, well-reported-and hence comparative references are made to developments in the USA throughout this paper. An established field in its own right, research on community schooling identifies some core characteristics of these initiatives internationally. Typically, they involve schools offering: additional arts, leisure, sports, and learning opportunities for students, extensive personal and social support, work with families, and learning, cultural, and leisure opportunities for local residents. Schools often also employ staff from non-educational backgrounds and develop partnerships with other child, family, and community agencies [11].

However, whilst there is some promising evidence about the impacts of community schools [12], it is also clear that both research and practice in the field of community schooling are badly under-conceptualized. Research on community schools is all too often of poor quality and frequently tied to enthusiastic, descriptive accounts of practice or advocacy for a particular community school 'model' [13-16]. Common critiques include that the well-established 'additive' model of community schooling, where services and out-of-hours activities are added to the core school day, essentially leave narrowly-focused school improvement models unchallenged [8]. Furthermore, such 'additive models' often take the form of recipes for action rather than a deeper consideration of some of the more fundamental causes of educational disadvantage. There are, for instance, many different rationales which might inform the work of a community school, each implying a different theory of change for how the school might mitigate the effects of disadvantage [8]. For instance, a strong focus on supporting the economic regeneration of the local area would suggest a rather different rationale to a strong focus on pastoral work with families.

Given the lack of clarity and criticality in the field, community schools have not surprisingly tended to be 'shape shifters'; as Dryfoos notes, 'in reality no two [community] schools are alike; they are all different' [17] (p. vii). This leaves community schools, like many other local-level initiatives to tackle educational disadvantage, open to the charge of being little more than displacement activities, distracting from the underlying socio-economic processes which generate inequalities [18-22]. Some might even argue that such initiatives are helpless in the face of what Lipman [23] characterizes as a brutal phase of 'coercive neoliberal urban governance', leading to the abandonment of the most disadvantaged places and populations.

Set against this, is a more optimistic view that complex initiatives like community schools need to learn their way to effectiveness, and that the field of community schooling can be significantly advanced by learning from these schools as they do so. Indeed, an emerging argument in the field suggests that these initiatives are evolving, leading to different overlapping 'generations' of community schooling $[24,25]$. This brings the promise that community school initiatives which may begin as somewhat opportunistic assemblages of services and activities around an essentially unreconstructed academic core, may, in later generations, develop much firmer conceptual foundations, and be capable of acting to address educational disadvantage in a much more coherent and strategic manner, marshalling the resources needed to do so. Specifically, as Lawson and van Veen [10] suggest, there may now be evidence of schools and their partners beginning to develop a 'new institutional design' that can enable such a shift. If this is indeed the case, this new generation of schools demands attention from practitioners and researchers. Both parties need, of course, to know what these schools do and how they operate. However, they also need to examine the conceptual thinking which underpins these schools' approaches, and how these underlying conceptualizations might be transferred to, and developed in, schools in very different contexts. We suggest this task requires a genuine partnership between the practitioners and policy makers seeking to develop these new designs, and the researchers trying to learn from their work-a theme which we return to later. 
Acting on these imperatives, this paper presents and analyses a case study of a community school in England — given the pseudonym 'City Academy' — which has strong claims to be part of a new generation of community schools. We approach our analyses with two principal questions in mind:

(1) What evidence is there of a 'new institutional design' at City Academy and in what ways is it distinctive?

(2) To what extent does this design embody new and plausible understandings of how the necessarily limited and local actions available to schools might nonetheless tackle the disadvantages experienced by children and their families and communities?

In the next section we describe the research on which the case study is based. We then describe what the Academy does to tackle disadvantage, the underpinning rationales for its actions, and the structures which support those actions. We use this account to explore the two questions above, arguing that the Academy does indeed demonstrate a new institutional design, and that this design embodies plausible understandings of how disadvantage might be tackled by schools. Finally, we explore the implications of this analysis for policy makers, practitioners, and researchers. The paper's contributions to knowledge are therefore empirical, in documenting the work of City Academy, and conceptual, in exploring the understandings underpinning this and how these might be used to advance the field of community schooling.

\section{The Evidence Base}

'City Academy' is located in England's second largest city and opened in 2010 to serve 11-19 year olds in one of the country's most disadvantaged neighborhoods. With some similarities to Charter Schools in the USA, academies are state-funded and controlled schools which operate more-or-less independently of local government. They are typically managed by 'sponsors' including private-sector businesses.

The study reported here is grounded in an ongoing, five year relationship between City Academy and the authors, both researchers from the Centre for Equity in Education. This relationship is characterized by a concern with exploring the problems and possibilities of practice as they emerge in the Academy, by mutuality, in which researchers and school practitioners jointly negotiate the focus of research and its implications for practice, and by a long-term commitment to a program of research, rather than to isolated, short-term projects. In this way, the relationship is an example of the 'research-practice partnerships' (RPPs) [26,27] that are currently emerging as a way of enabling research and practice to inform and enhance one another. The partnership has engaged in multiple research activities, generating rich data. To date, these have included: generating ethnographic field accounts of meetings, classroom, and other activities; instrumental case-studies [28] exploring specific aspects of City Academy's institutional design (for instance, a study of its community engagement practices, which included interviews with residents, Academy staff, and professionals from partner organizations and focus groups with students, plus observations of community engagement activities and analysis of documents relating to City's Academy's approach); and the development of a team of PhD researchers who have explored the views of the Academy's students and partner organizations on topics including community assets. Informed by this data, researchers and City Academy's leaders have worked together to formulate hypotheses about the impacts of the Academy's practices and structures and how these might be improved.

In particular, since 2013, the partnership has undertaken a major strand of activity built on principles of design-based implementation research $[29,30]$ and focused on the Academy's efforts to bring its extensive range of activity into a coherent strategic approach. The research team has synthesized the international research evidence on community schools and area-based initiatives in order to identify the most promising elements for such an approach [24,31,32], and have worked with City Academy's leaders to explore how they might act on these. One key element has been the development of a theory of change [33-36] setting out the understandings shared by City Academy 
and its partners about how disadvantage impacts on children locally, the long-term outcomes which are important for children and young people locally, the actions needed to bring about those outcomes, and the causal pathways they anticipate will link their proposed actions with their intended outcomes. This has required an iterative dialogue between the research team, City Academy's leaders, and their partners, and emerging findings from this process have been reported elsewhere [37].

As City Academy's plans have become more elaborate and more stable, being supported by a growing body of data, for the purposes of this paper it is now possible to interrogate the data to understand:

- what City Academy is doing to tackle disadvantage;

- why it is taking those actions-in terms of the conceptual rationales underpinning them;

- how these actions are supported by governance and organizational structures in and around the Academy.

From this, we should be able to identify the characteristics of any 'new institutional design' that may be emerging. We cannot, of course, make any assessment of how successful City Academy is at combatting disadvantage, for which a robust outcomes evaluation is required and has been planned. Indeed, it is entirely possible that even with a strongly plausible theory of change, City Academy might struggle to achieve its desired outcomes-and to deny this would be to fall into the trap of uncritical enthusiasm for which we have criticized other research in this field. We are not, therefore, claiming that City Academy embodies a proven, effective model for community schooling, but that an analysis of its work can yield conceptual insights essential to the development of any such model.

In saying this, it is also important to note that although the work of the Academy is in many ways distinctive, it of course draws on learning from previous initiatives in England-for instance, full-service schooling - many of which have been researched by the authors [8,24,38-41]. Since these initiatives share some of their conceptual underpinnings with the work of City Academy, this wider program of research has illuminated the current analysis and extends the warrant for the claims made here.

\section{The Academy's Approach}

\section{What the Academy Does}

City Academy offers a particularly extensive range of extra-curricular and out-of-hours activities to its students. It runs additional arts, sports, and leisure sessions every week, offers students access to community-run clubs, and provides holiday activities for children from the local area. These activities attempt to ensure that the Academy's students have access to similar opportunities to those available to their more advantaged peers elsewhere.

The Academy also seeks to combat directly the impacts of disadvantage on students' education. It provides uniform, sports kit, and cooking ingredients for all students, pays for them to take part in school trips, runs a 'breakfast club' before school, and ensures that they take part in the after-school activities on offer.

Moreover, the Academy offers strong personal and social support for students. It has a team of non-teacher specialists-attendance officers, an educational psychologist, welfare and safeguarding workers, a nurse, mental health workers, a counsellor, behavior specialists, and family support workers-some of whom are employed directly by the school and others brought in from other agencies. Their interventions are guided by a sophisticated tracking system which identifies the risks students are subject to, and monitors their attainment, behavior, and attendance, and other incidents that might signal that problems are arising.

There is also a distinctive approach to curriculum and teaching. England has a National Curriculum and set of accountability measures that have been framed in increasingly traditional academic terms [42]. However, City Academy has developed its teaching on the assumption that its 
students are likely to be alienated by such an approach and that learning has to be seen as being not just about passing examinations, but also about developing skills that will be of lifelong use. The focus, therefore, has to shift from what the teacher teaches to what the student learns and how s/he develops, with a consequent shift in the school's pedagogical technology. For instance, there is an emphasis on the development of 'soft skills' such as team working, problem solving, effective communication, and creative thinking. Instead of being designed around subject content, the curriculum is built around three key outcomes-being learning ready, being community ready, and being work ready. It is taught through an interdisciplinary, skills-focused approach, within a curriculum structure with five broad and inter-linked disciplinary areas: English and Maths, Health and Well-being, Science and Technology, Global Understanding, and Creative Arts. Lessons are driven by key learning outcomes rather than by subject content, and typically are team-taught with teachers and 'teaching assistants' working alongside each other. To facilitate this approach, the Academy's buildings are characterized by flexible teaching spaces rather than traditional 'box' classrooms.

Additionally, there is a strong career and technical element in the way the curriculum is delivered, and students have access to placements, internships, and opportunities to learn through addressing 'real life' problems developed in collaboration with the Academy's business partners. However, the aim is to offer students a range of possibilities, so the Academy also works closely with local universities and colleges to offer experiences related to higher education-for instance, working with university undergraduates on community projects. The Academy has also undertaken an exercise to map the economic growth sectors in the city and the full range of career pathways this opens up. The intention is that staff should be able to help students think through their futures in a well-informed and appropriately ambitious way.

Alongside its work with students, the Academy works to combat disadvantage and enhance opportunities in its locality by opening its facilities to local residents. The building is located on a highly visible site, central to the communities it serves, with an absence of fences and easy access from the street, and with internal spaces and sports and catering facilities dedicated to community activities.

As a learning resource for the whole community, the Academy offers a substantial program of adult learning activities. Currently some 250 learners are part of its 'community college'. There is a distinctive, planned approach which enables adult learners-many of whom have been disengaged from education for many years-to move from sport and cooking activities aimed at improving health outcomes, to more demanding activities aimed at acquiring qualifications, and then to accessing employment. The qualifications on offer are aligned with opportunities for employment locally and there is a 'job club' which supports adult learners in the search for employment. In addition, the Academy opens its facilities to community sports clubs and offers open access sports and leisure sessions. In total there are currently approximately 1300 community users every week.

Beyond this, the Academy sees itself as an agent of change in the communities it serves. It facilitates many projects which promote a positive view of the local area and empower its residents by supporting them to access new experiences and develop the capacity to take their own actions. For example, the Academy has supported the development of a local history group which seeks to engage residents in recapturing and valuing the area's past. This group has been formalized as a charitable organization, has a growing membership, and is highly active in the locality. In turn, City Academy's leaders are able to champion the area within wider strategic developments, most recently in helping to re-shape regeneration plans for the area.

\section{Why the Academy Takes These Actions}

City Academy was founded on the basis of a vision held by its stakeholders that schools should do more than offer an academic education to students and should instead play a significant role in enhancing the well-being of local communities. When City Academy was being planned (in the mid-2000s), central government was closing down urban schools with poor results one-by-one and replacing them with privately-sponsored academies, anticipating that this would drive up school 
performance [43]. In response to this, the local authority responsible for education in the city proposed an alternative model of 'academisation'. This involved: simultaneously building a group of new academies (of which City Academy was one) which were strategically located to act as educational hubs across the city; recruiting sponsors from the key growth sectors of the city's economy and linking curriculum and pedagogy to local economic development; and retaining the local authority's presence as a co-sponsor alongside private businesses, to ensure that the academies worked in ways aligned with wider strategies for regenerating the most disadvantaged parts of the city. City Academy, therefore, was established with broad aims:

to raise expectations and ultimately raise standards-of achievement, behavior, and attendance, and to help create sustainable communities, and progression beyond both school and employability [44].

This broad vision was subsequently developed into commitments to:

- a theme-based curriculum, leading to both vocational and academic qualifications, developing a range of skills and competences alongside academic knowledge, and delivered in creative ways seen as relevant by learners;

- developing the Academy as 'the hub of an organic learning community' including local residents as well as Academy students;

- $\quad$ establishing partnerships with other learning providers, businesses, and parents;

- an emphasis on collaborative teaching approaches;

- a foregrounding of 'student voice' as a means of encouraging young people to take ownership of their own learning and the development of the Academy [45].

These statements indicate a conceptualization of the role of the Academy as being more than 'just a school'. Moreover, they begin to indicate how the various aspects of the Academy's work might cohere together, with the academic, out-of-hours, guidance, and vocational work with students helping them do well as adults and to contribute to a 'sustainable community'. This, in turn, is supported by the development of a 'learning community' and by the close involvement of employers in City Academy. This coherence has been enhanced latterly by the development of a theory of change. This is articulated in a complex set of documents which go into some detail about the causal pathways linking the multiple actions taken by City Academy with a range of long-term and intermediate outcomes which those actions are expected to generate.

In broad terms, however, the analysis is straightforward:

- Children and young people in the area are seen as having their life chances limited by a series of challenges - 'unhealthy lifestyles... unsafe and unused public spaces...community stigma... disconnection of the community from the city and its opportunities... mistrust of professionals... poverty [and] unemployment-though there are also many assets in local communities which offer potential growth points';

- Underlying causes of this situation include the 'loss of traditional employment in heavy industry' and 'purpose built social housing - poor quality \& infrastructure' which together have produced a residualized population which has experienced a 'loss of pride' in the area;

- The long-term outcomes at which the Academy aims, therefore, include a reversal of the negative features of the area, but with the intentions that 'the community will access the same opportunities as those in more advantaged areas' and that the area will act 'as an escalator', enabling people to move onwards in their life and leave (if that is their choice) whilst at the same time recruiting new families to populate the area;

- All of this is to be achieved through a set of interlinked actions, including work focused on ‘Promoting longer healthier lives...securing better local health services...promoting healthier lifestyles... [c]hampioning [the area]... creating an active sense of community in [the area], pride 
in the area, promoting [the area] in the city, promoting [the area] to employers... [c]onnecting [the area] to [the] city... supporting people in [the area] to identify and access opportunities in the city', and so on [46].

In effect, this identifies the Academy not simply as a provider of education to school-age children, but as an agent of change and development within local communities. Moreover, it is no accident that the theory of change talks about 'people' rather than 'students' or even 'students' and 'adults'. It identifies the Academy's students not simply as decontextualized learners, but as community members, intimately involved in and impacted upon by the processes at work in the local area, and attending school, not simply to pass exams, but ultimately to take their place in the world outside the Academy.

\section{How Those Actions Are Supported}

City Academy's work is supported by structures that go beyond those normally associated with schools. Its leadership structure, for instance, includes a vice principal (community) with responsibility for community issues, who has a background in community work. She organizes the program of community-related activities, manages relationships with residents and community partners, and promotes the engagement of staff and students with local communities. She is supported by a 'community' team of non-teachers, and much of the personal and family support work is also undertaken by non-teachers.

To support its skills-based and vocationally-oriented curriculum, City Academy has developed a range of partnerships with local employers who provide learning and vocational placement opportunities for students. Moreover, the lead sponsor of the Academy is a large telecommunications organization. The principal reports that this organization was central to supporting the development of City Academy's vision, helping the Academy develop its concept of being 'employment ready', enabling it to access expert advice from the business world on the use of technology, and by continuing to provide vocationally-related learning experiences for students.

Beyond this, City Academy, led by the vice principal (community), works closely with community agencies and organizations. The continued presence of the local authority in the Academy's governance arrangements helps here, given that many community agencies are the authority's responsibility. In its early days, the Academy established a collaborative group aimed at bringing these organizations together to share knowledge and plan joint action. Its members now include the local social housing provider, the police, the local authority regeneration and adult education services, tenants and residents associations, local faith organizations, early years childcare services, local primary schools, a health practitioner, and local charitable organizations. The role of this group has expanded so that it is now taking on a formal governance role relating to the implementation of City Academy's theory of change.

It is, of course, important not to overstate the extent to which this group is as yet able to operate in a cohesive and dynamic manner, and City Academy remains a driving force, currently allocating its own resources to support the group's work. Crucially, however, the Academy does not in any sense 'own' or 'manage' the group, and the development of the group's role from information-sharing to decision-making is set to continue as it seeks to establish itself as a not-for-profit company which can bid for funding in its own right. At this point, it would also be difficult to argue that residents play a major role in the group's decision making, but City Academy and its partners nonetheless make strenuous efforts to listen to community voices and to support residents to establish their own community enterprises.

Finally, the Academy has extensive partnerships with higher education, not simply in offering opportunities to $\mathrm{PhD}$ students, but also in ensuring that its work is evidence-informed. The research partnership with the authors has helped inform the Academy's development, and City Academy has also set up a support group for PhD students researching the Academy, so that it can assist and learn from them and the students can support one another. 


\section{New Models}

Many elements of provision and practice at City Academy are familiar from the lengthy history of efforts to widen the role of schools in England and elsewhere. If City Academy is distinctive, therefore, it has to be in the configuration and intent of what it does. For instance, although the Academy is in many ways the center of student, family, and community-oriented provision, the initiative to develop this provision is not simply school-owned. It is built on a multi-stakeholder partnership and the ownership of that initiative has been vested explicitly in this wider stakeholder group, rather than the school itself.

This design is not accidental. Many full-service and community schools are focused on improving outcomes - usually educational outcomes—for their student populations [8]. To this extent, they seek to address children's personal and social problems so that they can make better use of the core academic learning opportunities on offer. This is certainly amongst the aims of City Academy. However, City Academy's aims are wider still. Its theory of change locates the challenges its students face in the history and characteristics of the local area-in a decline in manufacturing industry, a loss of pride in the area, and a disconnection of the community from opportunities in the rest of the city. City Academy therefore not only looks to achieve outcomes at a school and student level, but also at a community level-in terms of a restoration of pride, the achievement of economic vibrancy, and the creation of conditions under which both individuals and families can be successful.

Indeed, articulating a clear set of purposes is distinctive in itself. As we noted in the introduction, community school initiatives have suffered from a lack of clarity about their purposes. In England, for instance, government attention has been focused on specifying forms of provision, leaving individual head teachers to determine what outcomes they might hope to achieve in their particular contexts. Elsewhere in the world, such initiatives have tended to be based on some notion of meeting self-evident need, often combined with a view of the inadequacy of public services to meet those needs. As Joy Dryfoos, the pioneer of full-service schools in the USA put it, 'schools are failing because they cannot meet the complex needs of today's students' [47] (p. xvii), or, as Geoffrey Canada, then CEO of the highly-ambitious Harlem Children's Zone explained, the Zone was needed because, 'literally, all of the institutions are failing children' [48].

Such rationales, especially when only articulated at surface level rather than through a more comprehensive theory of change, inevitably run the risk of degenerating into the simple accumulation of diverse and disconnected forms of provision. At City Academy, however, provision and practice are built around a more fundamental analysis of how disadvantage 'works' in the local area and how it might be overcome. For this reason City Academy's approach goes beyond mere service-accumulation in at least two respects. One is the work around developing community pride and community agency-not simply supporting local residents, but drawing on their knowledge of the area and its history and mobilizing their cultural and other resources. The other is the tight coupling of City Academy's academic concerns and its wider work with children, families, and communities. Together, these avoid a 'student-fixing' model of community schooling, which simply adds non-educational services to otherwise unchanged schools and allows them to persevere with unreconstructed and ultimately alienating teaching and curricular practices [49]. At City Academy, by contrast, there is a real attempt to rethink curriculum and teaching so that they will be engaging to students, will develop the skills and attributes young people will need after school, and will be aligned with the demands of the local jobs market.

It is, of course, important not to overstate the difference between developments in and around City Academy and previous efforts to widen the role of schools. Nonetheless, what makes City Academy distinctive are the far-reaching aims, the provision and practices built around those aims, and the move away from a school-focused approach to partnership in favor of an area-based approach. In this sense it represents a new, more ambitious generation of efforts to widen the role of schools, retaining some characteristics of previous generations of community school models, but developing them in new directions $[24,25]$. 


\section{Learning from the Case}

What then can we learn from City Academy-in terms of conceptualizing the role a community school might play in tackling disadvantage, and the institutional design needed in order to play this role?

As we saw earlier, community schools face a contradiction between the substantial socio-structural processes which generate disadvantage and their own strictly limited capacities-or as one critic tellingly put it, 'the puny additional educational resources' typically dedicated to such initiatives have to be set 'against a backdrop of major social forces' [50] (p. 33).

However, this contrasts sharply with the more optimistic analysis implicit in City Academy's work. The theory of change there, as we have seen, acknowledges the impact of global economic forces in the decline of the local manufacturing industry and the destruction of community pride, but it also assumes that the area can once again become vibrant and that children and young people living locally are not doomed to experience disadvantage throughout their lives. Moreover, it assumes that this can be achieved through a range of actions that are within the capacity of the school and its partners-that somehow the provision of child and family support, the facilitation of community activities, engagement with local employers, and so on, can mitigate the impacts of macro-level forces. Whether these assumptions will hold good in practice remains to be seen, but for now, our concern is with whether they are theoretically credible.

To believe so implies relinquishing an entirely deterministic view of how macro-level forces shape disadvantaged areas and outcomes for their populations. It implies, firstly, that there is scope for local policies and circumstances not simply to mediate these forces, but to moderate them so that outcomes are markedly different in different places [51-53]. Moreover, it implies that even in the face of a neoliberal hegemony there may be possibilities at a local level for 'new conditions for resistance, new alliances, and possibilities for coalescence around a new social vision' [23] (p. 570).

Macro-level transformation may be far beyond the capacity of a local institution such as City Academy. However, City Academy nonetheless seeks to bring about significant changes in children and young people's lives, through actions that are strategic in their intent, incremental in their impact, and local in their scope. One way to think about this approach is to see it as grounded in an eco-systemic view of children's lives. Bronfenbrenner's well-known ecological systems theory, for instance, sees children as developing within a set of interacting systems and sub-systems, an 'ecological environment [which can be] conceived as a set of nested structures, each inside the next, like a set of Russian dolls' [54] (p. 3). On this view, family, school, neighborhood, and wider national contexts all play a role in shaping the child's outcomes, though they also shape each other, and the child in turn shapes them through the exercise of agency. Causality, in other words, is recursive rather than straightforwardly deterministic. The particular configuration and characteristics of systems and sub-systems therefore matter, and importantly these configurations and characteristics can be altered [55]. Schools can become more effective, families can be enabled to parent more productively, neighborhoods can be made safer, employers can increase local recruitment, and so on. In this way, a series of small but coherently aligned and strategically focused changes, within the scope of a school and its partners, might conceivably make a significant difference to the lives of individuals, and might, cumulatively over time, extend those differences across whole communities in the way that City Academy seems to envisage.

A second, related way of conceptualizing this process is through a framework of risk, resilience, and protection [56]. Rigorously interpreted, the notion of risk is important because it identifies factors in children's social ecologies that are associated (statistically) with poor outcomes and which may well be in some way causal of such outcomes. However, whatever the causal process is, it is clearly not deterministic since some children subject to risk factors nonetheless do well. The reason is that the risks these individuals are exposed to are balanced by other factors which appear to moderate the impact of risk. As Bartley [57] (p. 15) puts it, 'poverty and disadvantage can have different impacts, depending on the presence or absence of protective factors.' 
Viewed from this perspective, City Academy can be seen as attempting to reduce risks and enhance protective factors in the ecologies of children and young people. In providing them with engaging learning opportunities, opportunities outside of school hours, personal support for them and their families, and so on, it is seeking to change the ways those ecologies operate and so to moderate the impact of the macro-level factors which are otherwise likely to place them at a disadvantage. The interventions themselves are not large; they do not impact directly at the macro level. Yet this is not a reason to suppose that they are necessarily futile. As a major study of the factors underlying (educational) outcomes for children in England [58] (p. 71) has concluded:

It is never 'just' the one factor of child, family or school, or broader social context that brings about success or failure in an academic trajectory. Rather, it appears to be the particular ecological niches that arise through the active reciprocal interactions between these factors that determine the parameters for children's pathways to academic success. In other words, the real world context of development is complex but while characteristics at macro or meso level, such as school policies and curriculum or parental jobs, exert some influence on children's day-to-day learning experiences, the best opportunities to help children are within reach right there on the micro level.

If Siraj-Blatchford [58] is right that it is 'the active reciprocal interactions between... factors' that matters, this begs the question of what kind of organization does a school need to be-or to become part of-in order to impact on such factors. Does it need to reconstitute itself around a 'new institutional design' [10]? As we have argued throughout, City Academy is not 'just a school'. It is an organization which takes the core functions of schooling-teaching, providing access to a curriculum, managing behavior, and so on-shapes them towards ends which go beyond purely educational outcomes, and combines them with other kinds of actions which support these wider ends. City Academy has reconfigured its structures and practices internally in order to pursue a social rather than purely educational mission. It might, therefore, be appropriate to regard it as a 'social enterprise', defined as 'a business that trades for a social and/or environmental purpose [with] a clear sense of its 'social mission' [59].

If this is so, then in acting as a social enterprise, City Academy ceases to operate as an individual, quasi-autonomous institution, and instead operates as part of an increasingly cohesive grouping of partner organizations which share aims, formulate common strategies in pursuit of those aims, and pool resources to make those strategies viable. It appears, therefore, as an example of what is sometimes referred to as 'interactive governance' [60-63]. Although this term is used differently by different authors, it essentially refers to a family of governance approaches emerging as a reaction to the perceived inability of both centralized government and market forces to tackle complex societal problems. Such complexity, the advocates of interactive governance argue, calls for multiple social actors to pool their resources in a common endeavor. This cannot happen effectively in the context of hierarchical relationships in which central government or some other institution seeks to exercise command and control. Instead, actors have to come together in 'networks' characterized by mutuality, interdependence, resource exchange, significant autonomy from the state, and collaboration across sectoral and organizational boundaries [64,65]. City Academy is working towards such an arrangement.

Arguably, what is happening in and around City Academy is a response to the erosion of established patterns of service provision and governance in England. For the past century, a wide range of relatively well-resourced public services-including education, social care, and housing-has been provided at the local level by democratically elected local councils, able to shape those services to the needs of particular areas and mediate between central government imperatives and the needs of their localities. From the 1980s onwards, this local control began steadily to be eroded by central government attempts to introduce market forces into the provision of public services, not least in the school system, where the introduction of academies is a prime example of such efforts [66]. Latterly, the established system has suffered further shocks. The 2008 financial crisis led to a significant reduction 
in the resources available to local services [67], while the return of center and center-right governments with an intent to 'shrink the state' [68] has further reduced local capacity. As a result, something of a vacuum in service provision and governance has been created into which new organizational forms are beginning to emerge at the local level. City Academy, as neither a traditional school nor a traditional local government structure, is one such example.

If, then, City Academy is indeed an example of a new 'networked social enterprise' design, the question arises as to what holds this network together. The Academy and its partners are not obliged to work together in other than the most cursory way. They choose to do so to deliver a strategy, expressed in their theory of change, to which they are all signed up and they are currently exploring how best to strengthen and formalize their partnership. To this extent, they may be seen as an example of what is sometimes known as 'public value management' [69]. Stoker [70] explains that this has arisen through a process where traditional 'public administration' by strong and highly autonomous local government was replaced by a centrally-controlled, target- and accountability-driven 'new public management', which is, in turn, giving way to a new form of management that has:

Public value as its core objective. Public value is more than a summation of the individual preferences of the users or producers of public services... For the public value management paradigm, the understanding of the public interest, the nature of the public service ethos, the role of managers, and the contribution of democratic processes stand in contrast to traditional public administration and new public management [70] (p. 42).

Public value management, therefore, crucially depends on professionals and public organizations voluntarily pooling their efforts on the basis of a negotiated and shared understanding of what constitutes public value in a particular set of circumstances. Such negotiations are arguably the only way to bring organizations together when traditional structural hierarchies and accountability mechanisms are gone.

All of this enables us to conceptualize City Academy in a distinctive way. City Academy is a risk-reducing, resilience-building intervention in the ecologies of children and young people facing significant disadvantage. This means it has to move beyond being 'just a school'. It has to reshape its internal structures and practices in order to pursue a social, rather than purely educational, mission. It also has to engage with partner organizations in strategic action. Precisely because this action is strategic, it involves more than the incidental collaborations that are familiar in and around community schools. Rather, it has to build stable, long-term, and highly cohesive relationships so that all the participating organizations become part of the social enterprise. This means City Academy has to participate alongside those other organizations in network governance. This cannot be achieved through traditional forms of public governance, so it has instead to be achieved through something like public value management.

\section{Some Implications}

We began our exploration of City Academy with two questions, about whether the Academy embodies a 'new institutional design' and whether that design embodies new and plausible understandings about how local actions in and around schools might tackle disadvantage. The foregoing analysis suggests answers very much in the affirmative. City Academy has moved well beyond the traditional notion of what a school is and, indeed, of what a community school might be. Moreover, its capacity to act as a risk-reducing, resilience-building intervention suggests a way in which the necessarily limited actions it can marshal might indeed impact on the disadvantages experienced by the children, families, and communities it serves.

If this is the case, there are significant implications for policy makers, practitioners, and community school researchers internationally. If policy makers are to address the challenge of tackling educational and wider social disadvantage, then new understandings of the role schools might play in meeting that challenge, and of the new kinds of design this entails, are needed. City Academy was founded at 
a time of significant policy experimentation in England, not only in terms of establishing academies, but also an ambitious attempt to extend the role of all schools to both educational and non-educational outcomes, in alignment with other child and family services [71]. This experiment was short-lived and ended abruptly with the election of a center-right government in 2010. Nonetheless, for a brief while serious policy consideration was given to what a '21st century school' [72] might look like. This implies that the traditional structures and purposes of schools need not be fixed and that, even within the constraints of a dominant neoliberal policy agenda, some creative thinking is possible. It is arguable that the erosion of public services that marks the 'shrinking of the state' in many countries makes the rethinking of traditional institutions such as the school yet more urgent. Without this, the most disadvantaged places in particular are likely to be subject to the processes of abandonment of which Lipman [23] warns.

There are also significant implications for practitioners, particularly school leaders and their partners in other agencies. Although City Academy was established at a time of policy experimentation, its development over time has been due to the willingness of its leaders to rethink in a profound way the role of the school. The implication is that such rethinking is possible, even in somewhat unpromising policy environments. There is, therefore, a responsibility for school leaders to consider how they might extend the role of their schools beyond their core educational functions, and therefore what it might mean for their schools to become networked social enterprises, focused on the tasks of risk-reduction and resilience-building. These leaders need support, of course. They need help to think these issues through, access to examples of new designs in action, and training for a role which is very different from that of a leader of a 'traditional' school. There are implications here for those agencies and organizations that support school leaders, whether they are central government agencies, or local government services, or university trainers and researchers.

Finally, our analysis has implications for research. The new institutional designs that City Academy represents are characterized by complexity, in terms of their aims, interventions and organizational structures. They demand research and evaluation designs that are capable of capturing that complexity and evaluating its outcomes. However, City Academy and its like are also experimental and developmental. Researchers need not only to describe these designs and evaluate their impacts, but also - as we have tried to do here-to surface the underpinning conceptualizations of what schools are, what they are for, and what role they might play in tackling disadvantage. Moreover, they need to do this while the schools are 'on the move', viewing them as sets of hypotheses that are being tested and understanding how those hypotheses are constantly being reformulated in the light of experience.

Crucially, the principal experimenters here are not the researchers. They are practitioners and policy makers faced daily with the challenges of improving outcomes for disadvantaged children, equipped with practices and institutions that increasingly seem inadequate for this task, and who undertake 'natural' experiments to develop new practices and new institutional designs. The task for researchers is to work alongside these experimenters-in-practice, to learn from what they do, to synthesize that learning with the best of existing research and scholarship, and to enable that synthesis to be fed back into the design process so that it is increasingly evidence-based and robustly theorized. It seems to us that the recent developments in research-practice partnerships, and in design-based implementation research to which we referred earlier, offer a highly promising way forward in this respect. Partnerships of this kind, of course, have significant implications for how research is funded and for how leaders in higher education view the role of their institutions in tackling fundamental social problems [73]. However, if such partnerships can be supported so that they become characteristic of the field, there is every prospect that approaches like City Academy's will open the way to a more profound understanding of what a new generation of community schools might be capable of achieving. They can set a direction for design-based research which can significantly advance the field of community schooling, conceptually and empirically, while also holding the promise of being able to achieve better outcomes for children and young people, even as learning in the field progresses. 
Author Contributions: Kirstin Kerr is the lead academic for the Centre for Equity in Education's research-practice partnership with City Academy and both authors have undertaken reported research activities. The authors have made equal contributions to the writing of the paper.

Conflicts of Interest: The authors declare no conflict of interest.

\section{References}

1. Ballas, D.; Lupton, R.; Kavroudakis, D.; Hennig, B.; Yiagopoulou, V.; Dale, R.; Dorling, D. Mind the Gap: Education Inequality across EU Regions; NESSE Network of Experts for the European Commission: Brussels, Belguim, 2012.

2. European Commission Directorate-General for Education and Culture. Education and Training Monitor 2015; Publications Office of the European Union: Luxembourg, Luxembourg, 2015.

3. OECD. Equity and Quality in Education: Supporting Disadvantaged Students and Schools; OECD Publishing: Paris, France, 2012.

4. OECD. Are Countries Moving towards More Equitable Education Systems? Pisa in Focus 25. Available online: http://www.oecd-ilibrary.org/education/are-countries-moving-towards-more-equitableeducation-systems_5k4bwpbqrz9s-en (accessed on 1 August 2013).

5. OECD. Low-Performing Students: Why They Fall behind and How to Help Them Succeed; PISA: Paris, France, 2016.

6. Muijs, D. Effectiveness and disadvantage in education: Can a focus on effectiveness aid equity in education? In Education and Poverty in Affluent Countries; Raffo, C., Dyson, A., Gunter, H., Hall, D., Jones, L., Kalambouka, A., Eds.; Routledge: London, UK, 2010; pp. 85-96.

7. Strand, S. Do some schools narrow the gap? Differential school effectiveness revisited. Rev. Educ. Online 2016, 4, 107-144.

8. Cummings, C.; Dyson, A.; Todd, L. Beyond the School Gates: Can Full Service and Extended Schools Overcome Disadvantage; Routledge: London, UK, 2011.

9. Edwards, A.; Downes, P. Alliances for inclusion: Cross-sector Policy Synergies and Interprofessional Collaboration in and around Schools; European Commission: Brussels, Belguim, 2013.

10. Lawson, H.A., van Veen, D., Eds.; Developing Community Schools, Community Learning Centers, Extended-Service Schools and Multi-Service Schools: International Exemplars for Practice, Policy, and Research; Springer International: Dordecht, The Netherlands, 2016.

11. Coalition for Community Schools. Frequently Asked Questions about Community Schools. Available online: http:/ / www.communityschools.org/index.php?option=content\&task=view\&id=6\&Itemid=27 (accessed on 2 April 2010).

12. Blank, M.; Melaville, A.; Shah, B. Making the Difference: Research and Practice in Community Schools; Coalition for Community Schools, Institute for Educational Leadership: Washington, DC, USA, 2003.

13. Henderson, A.T.; Mapp, K.L. A New Wave of Evidence: The Impact of School, Family, and Community Connections on Student Achievement: Annual Synthesis 2002; Southwest Educational Development Laboratory: Austin, TX, USA, 2002.

14. Keyes, M.C.; Gregg, S. School-Community Connections: A Literature Review; AEL: Charleston, WV, USA, 2001.

15. Robson, B. Area-based policy evaluation. In Evaluating Local Economic and Employment Development: How to Assess What Works among Programmes and Policies; OECD: Paris, France, 2005; pp. 199-220.

16. Wilkin, A.; White, R.; Kinder, K. Towards Extended Schools: A Literature Review; DFES: London, UK, 2003.

17. Dryfoos, J.G. Preface. In Community Schools in Action: Lessons from a Decade of Practice; Dryfoos, J.G., Quinn, J., Barkin, C., Eds.; Oxford University Press: Oxford, UK, 2005; pp. v-viii.

18. Power, S.; Gewirtz, S. Reading Education Action Zones. J. Educ. Pol. 2001, 16, 39-51. [CrossRef]

19. Power, S.; Rees, G.; Taylor, C. New Labour and educational disadvantage: The limits of area-based initiatives. Lond. Rev. Educ. 2005, 3, 101-116. [CrossRef]

20. Raffo, C.; Dyson, A. Full service extended schools and educational inequality in urban contexts-New opportunities for progress? J. Educ. Pol. 2007, 22, 263-282. [CrossRef]

21. Rees, G.; Power, S.; Taylor, C. The governance of educational inequalities: The limits of area-based initiatives. J. Comp. Pol. Anal. 2007, 9, 261-274. [CrossRef] 
22. Rochex, J.-Y. Twenty-five years of priority education policy in France: Dubious specificity and disappointing results. In Education Policies and Inequalities in Europe; Demeuse, M., Frandji, D., Greger, D., Rochex, J.-Y., Eds.; Palgrave Macmillan: Basingstoke, UK, 2012; pp. 93-126.

23. Lipman, P. Economic crisis, accountability, and the state's coercive assault on public education in the USA. J. Educ. Pol. 2013, 28, 557-573. [CrossRef]

24. Kerr, K.; Dyson, A.; Raffo, C. Education, Disadvantage and Place: Making the Local Matter; Policy Press: Bristol, UK, 2014.

25. Lawson, H.A. Third-generation partnerships for P-16 pipelines and cradle-through-career education systems. Peabody J. Educ. 2013, 88, 637-656. [CrossRef]

26. Coburn, C.E.; Penuel, W.R. Research-practice partnerships in education: Outcomes, dynamics, and open questions. Educ. Res. 2016, 45, 48-54. [CrossRef]

27. Coburn, C.E.; Penuel, W.R.; Geil, K.E. Research-Practice Partnerships at the District Level: A New Strategy for Leveraging Research for Educational Improvement; William, T., Ed.; Grant Foundation: New York, NY, USA, 2013.

28. Yin, R.K. Case Study Research: Design and Methods, 5th ed.; Sage: London, UK, 2014.

29. Anderson, T.; Shattuck, J. Design-based research: A decade of progress in education research? Educ. Res. 2012, 41, 16-25. [CrossRef]

30. Fishman, B.J.; Penuel, W.R.; Allen, A.-R.; Cheng, B.H.; Sabelli, N. Design-based implementation research: An emerging model for transforming the relationship of research and practice. In National Society for the Study of Education, 112th Yearbook; Teachers College Press: New York, NY, USA, 2013; Volume 112, pp. 136-156.

31. Dyson, A.; Kerr, K. Developing Children's Zones for England: What's the Evidence; Save the Children: London, UK, 2013.

32. Kerr, K.; Dyson, A. Developing an evidence-based rationale for a Children's Zone approach. Int. J. Res. Ext. Educ. 2014, 2, 97-112.

33. Anderson, A. An introduction to theory of change. Eval. Exch. 2005, 11, 12-19.

34. Connell, J.; Klem, A.M. You can get there from here: Using a theory of change approach to plan urban education reform. J. Educ. Psychol. Consult. 2000, 11, 93-120. [CrossRef]

35. Connell, J.P.; Kubisch, A.C. Applying a theory of change approach to the evaluation of comprehensive community initiatives: Progress, prospects and problems. In New Approaches to Evaluating Community Initiatives. Volume 2: Theory, Measurement and Analysis; Fulbright-Anderson, K., Kubisch, A.C., Connell, J.P., Eds.; The Aspen Institute: Queenstown, MD, USA, 1998; pp. 15-44.

36. Dyson, A.; Todd, L. Dealing with complexity: Theory of change evaluation and the full service extended schools initiative. Int. J. Res. Method Educ. 2010, 33, 119-134. [CrossRef]

37. Dyson, A.; Kerr, K.; Heath, L.; Hodson, P. From school to Children's Community: The development of Manchester Communication Academy, England. In Developing Community Schools, Community Learning Centers, Extended-Service Schools and Multi-Service Schools: International Exemplars for Practice, Policy, and Research; Lawson, H.A., van Veen, D., Eds.; Springer International: The Hague, The Netherlands, 2016; pp. 346-383.

38. Dyson, A.; Gallannaugh, F.; Kerr, K. Conceptualizing School-Community Relations in Disadvantaged Areas. Available online: http://www.ahrc.ac.uk/documents/project-reports-and-reviews/connectedcommunities/conceptualising-school-community-relations-in-disadvantaged-areas/ (accessed on 23 February 2016).

39. Dyson, A.; Kerr, K. Taking Action Locally: Schools Developing Innovative Area Initiatives; Centre for Equity in Education: Manchester, UK, 2011.

40. Dyson, A.; Kerr, K.; Raffo, C. Area-based initiatives in England: Do they have a future? Rev. Fr. Pédag. Rech. Educ. 2012, 178, 27-38. [CrossRef]

41. Dyson, A.; Kerr, K.; Weiner, S. Schools and Their Communities: Vision and Impact; SSAT: London, UK, 2011.

42. Vasagar, J.; Shepherd, J. National Curriculum Review Puts Emphasis on Facts. Available online: http:// www.theguardian.com/education/2011/jan/20/national-curriculum-review-facts-and-vital-knowledge (accessed on 21 December 2015).

43. DfEE. City Academies: Schools to Make a Difference. A Prospectus for Sponsors and Other Partners. Available online: http://dera.ioe.ac.uk/3000/1/City_academies_-_schools_to_make_a_difference_(July_ 2000).pdf (accessed on 1 October 2010).

44. City Academy Sponsor. Sponsor's expression of interest document. Unpublished work, no date. 
45. City Academy. Vision and Ethos Statement. Unpublished work, 2007.

46. City Academy. Draft theory of change document. Unpublished work, no date.

47. Dryfoos, J. Full-Service Schools; Jossey-Bass: San Francisco, CA, USA, 1994.

48. Nauffts, M. Geoffrey Canada, President/CEO, Harlem Children's Zone, Inc.: Improving outcomes for children and youth through a place-based strategy. Philanthropy News Digest, 17 October 2002. Available online: http://philanthropynewsdigest.org/newsmakers/geoffrey-canada-president-ceo-harlem-childrens-zone-inc.-improving-outcomes-for-children-and-youth-through-a-place-based-strategy (accessed on 2 April 2015).

49. Edwards, A.; Lunt, I.; Stamou, E. Inter-professional work and expertise: New roles at the boundaries of schools. Br. Educ. Res. J. 2010, 36, 27-45. [CrossRef]

50. Smith, G. Whatever happened to Educational Priority Areas? Oxf. Rev. Educ. 1987, 13, 23-38. [CrossRef]

51. Dyson, A.; Gunter, H.; Hall, D.; Raffo, C.; Jones, L.; Kalambouka, A. What is to be done? Implications for policy makers. In Education and Poverty in Affluent Countries; Raffo, C., Dyson, A., Gunter, H., Hall, D., Jones, L., Kalambouka, A., Eds.; Routledge: London, UK, 2010; pp. 195-215.

52. Sampson, R.J. Great. American City: Chicago and the Enduring Neighbourhood Effect; University of Chicago Press: Chicago, IL, USA, 2012.

53. Wacquant, L. Urban Outcasts: A Comparative Sociology of Advanced Marginality; Polity Press: Cambridge, MA, USA, 2008.

54. Bronfenbrenner, U. The Ecology of Human Development: Experiments by Nature and Design; Harvard University Press: Cambridge, MA, USA, 1979.

55. Lee, C.D. Conceptual and methodological challenges to a cultural and ecological framework for studying human learning and development. In Research on Schools, Neighborhoods, and Communities: Toward Civic Responsibility; Tate, I.V., William, F., Eds.; Rowman \& Littlefield for AERA: Plymouth, MA, USA, 2012; pp. 173-202.

56. Schoon, I. Risk and Resilience: Adaptations in Changing Times; Cambridge University Press: Cambridge, UK, 2006.

57. Bartley, M. Capability and Resilience: Beating the Odds; UCL: London, UK, 2006. Available online: http://www.ucl.ac.uk/capabilityandresilience/beatingtheoddsbook.pdf (accessed on 29 February 2016).

58. Siraj-Blatchford, I.; Mayo, A.; Melhuish, E.; Taggart, B.; Sammons, P.; Sylva, K. Performing Against the Odds: Developmental Trajectories of Children in the EPPSE 3-16 Study; Research Report DFE-RR128; DfE: London, UK, 2011.

59. Social Enterprise UK. Social Enterprise FAQs. Available online: http://www.socialenterprise.org.uk/about/ about-social-enterprise/FAQs (accessed on 22 February 2016).

60. Hambleton, R.; Sweeting, D. Interactive governance: A view from the UK. In The Rise of Interactive Governance and Quasi-Markets; Denters, B., Van Heffen, O., Huisman, J., Klok, P.-J., Eds.; Kluwer: Dordrecht, The Netherlands, 2003; pp. 239-259.

61. Kooiman, J.; Bavinck, M. Theorizing governability-The interactive governance perspective. In Governability of Fisheries and Aquaculture: Theory and Applications; Bavinck, M., Chuenpagdee, R., Jentoft, S., Kooiman, J., Eds.; Springer: Dordecht, The Netherlands, 2013; pp. 9-30.

62. Sørensen, E. Institutionalizing interactive governance for democracy. Crit. Policy Stud. 2013, 7, 72-86. [CrossRef]

63. Torfing, J., Peters, B.G., Pierre, J., Sørensen, E., Eds.; Interactive Governance: Advancing the Paradigm; Routledge: London, UK, 2012.

64. Ball, S.; Junemann, C. Networks, New Governance and Education; Policy Press: Bristol, UK, 2012.

65. Sørensen, E.; Torfing, J. Introduction: Governance network research: Towards a second generation. In Theories of Democratic Network Governance; Sorensen, E., Torfing, J., Eds.; Palgrave Macmillan: Basingstoke, UK, 2007; pp. 1-21.

66. Kerr, K. English society and education: Historical and contemporary inequalities and challenges. In Equity and Education in Cold Climates in Sweden and England; Beach, D., Dyson, A., Eds.; Tufnell: London, UK, 2016; pp. 60-79.

67. National Audit Office. The Impact of Funding Reductions on Local Authorities; National Audit Office: London, UK, 2014. 
68. Feigenbaum, H.; Hennig, J.; Hamnett, C. Shrinking the State: The Political Underpinnings of Privatization; Cambridge University Press: Cambridge, MA, USA, 1998.

69. Marcon, G. Public value theory in the context of public sector modernization. In Public Value Management, Measurement and Reporting (Studies in Public and Non-Profit Governance, volume 3); Guthrie, J., Marcon, G., Russo, S., Farneti, F., Eds.; Emerald Group Publishing: Bingley, UK, 2014; pp. 323-351.

70. Stoker, G. Public Value Management: A new narrative for networked governance? Am. Rev. Public Adm. 2006, 36, 41-57. [CrossRef]

71. Dyson, A.; Kerr, K. Out of school time and extended services in England: A remarkable experiment. J. Educ. Res. Online 2014, 6, 76-94.

72. DCSF. 21st Century Schools: A World-Class Education for Every Child. Available online: http://webarchive. nationalarchives.gov.uk/20100916140730/publications.education.gov.uk/default.aspx?pagefunction= productdetails\&pagemode=publications\&productid=dcsf-01044-2008 (accessed on 17 April 2016).

73. Campbell, H.; Vanderhoven, D. Knowledge That Matters: Realising the Potential of Co-Production. Available online: http:/ / www.n8research.org.uk/media/Final-Report-Co-Production-2016-01-20.pdf (accessed on 7 June 2016).

(C) 2016 by the authors; licensee MDPI, Basel, Switzerland. This article is an open access article distributed under the terms and conditions of the Creative Commons Attribution (CC-BY) license (http://creativecommons.org/licenses/by/4.0/). 